British Journal of Environmental Sciences

Vol.10, No.2, pp. 1-12, 2022

ISSN 2054-6351 (print),

ISSN 2054-636X (online)

\title{
SUSTAINABLE AGRICULTURE AS A TOOL FOR IMPROVING BIODIVERSITY AND ECOSYSTEM SERVICES WITHIN THE BELEPIENI CATCHMENT OF THE UPPER EAST REGION, GHANA
}

\author{
Adonadaga, M.G' ${ }^{1 *}$; Analem, $\mathbf{J}^{1}$; Ampadu, $\mathbf{B}^{1}$ \\ C. K. Tedam University of Technology and Applied Sciences, School of Environment and Life Sciences, \\ Department of Environmental Science, Navrongo, Ghana.
}

Citation: Adonadaga, M.G; Analem, J; Ampadu, B (2022) Sustainable Agriculture as a Tool for Improving Biodiversity and Ecosystem Services within the Belepieni Catchment of the Upper East Region, Ghana, British Journal of Environmental Sciences, Vol.10, No.2, pp. 1-12

\begin{abstract}
The immediate and long term effects of climate change in sub-Saharan Africa include desertification, land degradation and food insecurity. These effects are expected to worsen in the coming decades, with attendant consequences on ecosystems and biodiversity services. This research assessed the potential of sustainable agriculture as a means for restoring and improving upon the biological diversity and ecosystem services within the Belepieni catchment, a predominantly agricultural landscape. The study considered the current trend in terms of the main environmental parameters, the drivers of change and the opportunities for addressing the current situation within the catchment. Although population growth remains the major driver, several opportunities such as high labour force, access to extension services, availability of market for produce, and most importantly traditional knowledge on farming practices also exist. A management approach based on the Climate and Ecosystem Change Adaptation and Resilience framework is proposed for improving the ecological, socio-economic and engineering resilience of the catchment.
\end{abstract}

KEYWORDS: climate resilience, sustainable agriculture, biodiversity and ecosystem function, Belepieni catchment

\section{INTRODUCTION}

The science of climate change is convincing now than ever before, with projections indicating Africa to be the hardest hit despite being the lowest contributor to global fossil fuel emissions (Canadell et al., 2009; Boadi and Owusu, 2017). For instance, temperatures are projected to rise faster than the global average increase, particularly in the more arid regions of Africa (IPCC, 2001; 2007; 2018). Regarding precipitation, available data indicates that rainfall patterns are significantly changing with a decline in mean annual precipitation over the past century in many parts of Western Africa, with these changes expected to be amplified in the future regardless of future emissions. Such changes are likely to affect food security, water availability and natural systems of Sub-Saharan Africa (SSA) because of its high exposure, sensitivity and weak adaptive capacity to climate conditions (Niang et al., 2014). This will intensify the already adverse livelihood conditions since many rural communities are strongly dependent on natural resources from their immediate environment. The result will be a magnification of already occurring stressors such as land degradation, desertification, and deforestation in many parts of rural Sub-Saharan Africa.

Two types of drivers of change can be identified; the natural drivers and anthropogenic drivers. These are responsible for the immediate cause of changes in nature, and consequently affect the supply of the benefits

ECRTD-UK https://www.eajournals.org/

ULR:https://doi.org/10.37745/bjes.2013 
of nature to humans (IPBES, 2015). Natural drivers such as climate change affect nature directly by determining the distribution of ecosystems and biomes on Earth (Chapin et al., 2011). These effects could result from natural events of massive proportion such as volcanic eruptions and meteorite impacts which can cause ecosystem destruction while at the same time provide needed material by way of fertile soils for development of new species and other pioneer plants (Blumetti et al., 2007; Vellekoop et al., 2014). Additionally, direct drivers can have effects on anthropogenic assets, as in the case when houses, water and electricity transmission systems are destroyed or disrupted by natural events such as earthquakes or hurricanes. Direct drivers can also impact on the quality of life as in the case of high temperatures as a result of climate warming or flooding resulting in deaths.

The ecological zones of Ghana range from guinea savanna to tropical forest, and have supported livelihoods for centuries where majority of the people always depended on agriculture and the yield of natural ecosystems. Hence, the use of sustainable and traditional land and resource management practices is key to the resilience of such ecosystems (Davies, 2002). According to Millennium Ecosystem Assessment Synthesis (2005) and FAO (2018), ecosystem services can be classified into four main categories; supporting, provisioning, regulating services and cultural. These ecosystems provide the foundation for production of various goods such as crops, wild foods, medicinal plants, fodder, materials for building and firewood, as well as a source of income generation to reduce poverty. For instance, subsistence farmers in northern Ghana are able to cultivate staple crops such as groundnuts, maize, pepper within their ecological space, on yearly basis, thereby ensuring food security (SEPLS, 2016). In addition, these ecosystems provide regulatory services such as soil fertility, water regulation, disease and pest control and also pollination. These services, although often poorly recognised and underestimated, provide the balances for the functioning of the other components of the ecosystem (Adekola, et al., 2015). According to Robertson et al. (2005), Zhang et al. (2007) and Lepczyk et al. (2017), agricultural systems must additionally provide other services that are supporting and regulating in nature, such as soil fertility, pest control and pollination. Hence, agriculture and its associated management practices on biophysical systems must be seen in a much larger and broader context with regards to ecosystem services because of the multiple synergies, trade-offs, and other non-linear relationships that can be derived from multiple levels in agro-ecosystems (Bennett $e t$ al., 2009; FAO, 2018). For example, the application of fertilizer may result in increase in crop yields (positive) on one hand but a decrease in water quality (negative) on the other hand although these services are not functionally linked. Ecosystems also provide supporting services to the world's biological and genetic diversity (UNEP, 2008; FAO, 2018). Savanna ecosystems provide support for vulnerable species of monkeys and other terrestrial and arboreal animals.

Therefore, development and implementation of effective strategies aimed at enhancing the resilience of such ecosystems deserves a particular attention. The study area is endemic with poverty (World Bank, 2015) although agriculture is the backbone of the local economy. However, due to the location of the area in the savannah ecological zone which has a uni-modal rainfall season lasting for a period of seven months (Ampadu et al., 2019), the agricultural activity in the area is bedevilled with this harsh climatic weather conditions with most of the farmers having nothing to do during the dry season, except few of them who engage in irrigation gardening. Consequently, the need for sustainable agriculture to restore biodiversity is

ECRTD-UK https://www.eajournals.org/

ULR:https://doi.org/10.37745/bjes.2013 
crucial. This study assessed how sustainable agriculture can be applied to reduce the effects of climate change and improve on biodiversity and ecosystems services within the Belepieni catchment in the savanna ecological zone of the Upper East Region of Ghana.

\section{METHODOLOGY}

The study was conducted at the Belepieni catchment which is located in the Upper East Region of Ghana and extends into Burkina Faso (Figure 1). It lies within four districts in the Region: Builsa North and South and Kassena Nankana East and West. The catchment lies along one of the tributaries of the White Volta River (Belepieni River) within the Volta Basin. The Tono Dam and its irrigable area fall within this catchment.

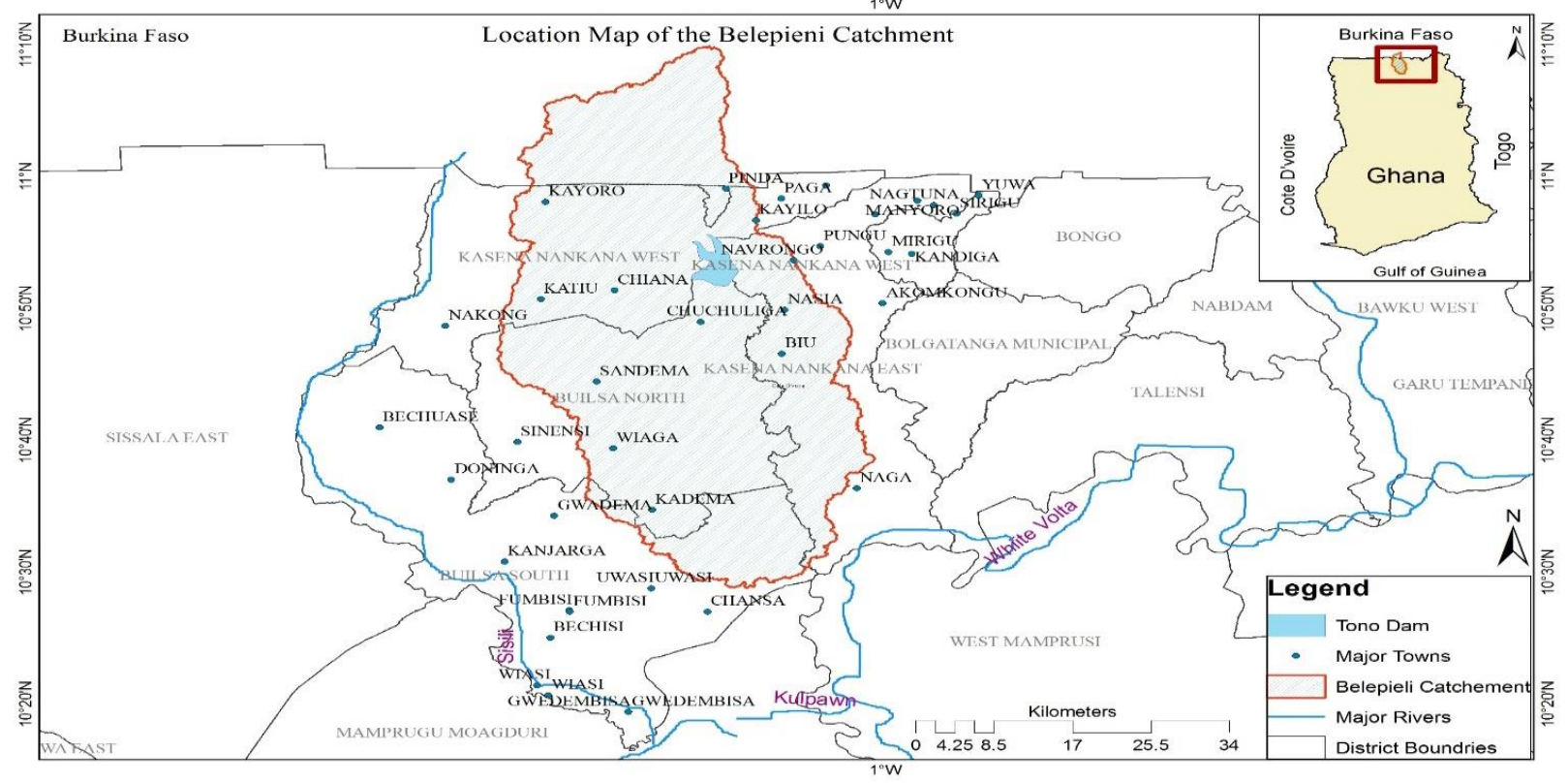

Figure 1. A Map of Ghana showing the location of the Belepieni River Catchment

Species occurrence distribution of the Upper East region, annual rainfall, temperature and population distribution maps of Ghana, showing the Belepeni catchment were drawn based on secondary data. Drivers for the declining biodiversity within the area, challenges faced by the catchment with regards to biodiversity conservation and opportunities for reversing the declining trend of biodiversity are discussed. Finally, a management approach is suggested based on the socio-economic and ecological dimensions of the catchment, with reflections on potential trade-offs and constraints for its implementation.

ECRTD-UK https://www.eajournals.org/ ULR:https://doi.org/10.37745/bjes.2013 


\section{RESULTS}

\section{Population}

According to the 2010 population census of Ghana, the number of people within the four districts, Builsa North and South, Kassena-Nankana East and West, stood at 56477, 36514, 109944 and 70667 respectively (Ghana statistical Service, 2014). With an annual intercensal growth rate of 1.2 within the districts, there will be an increase of about $12.6 \%$ of the total population within the catchment by year 2020 (GSS, 2014).

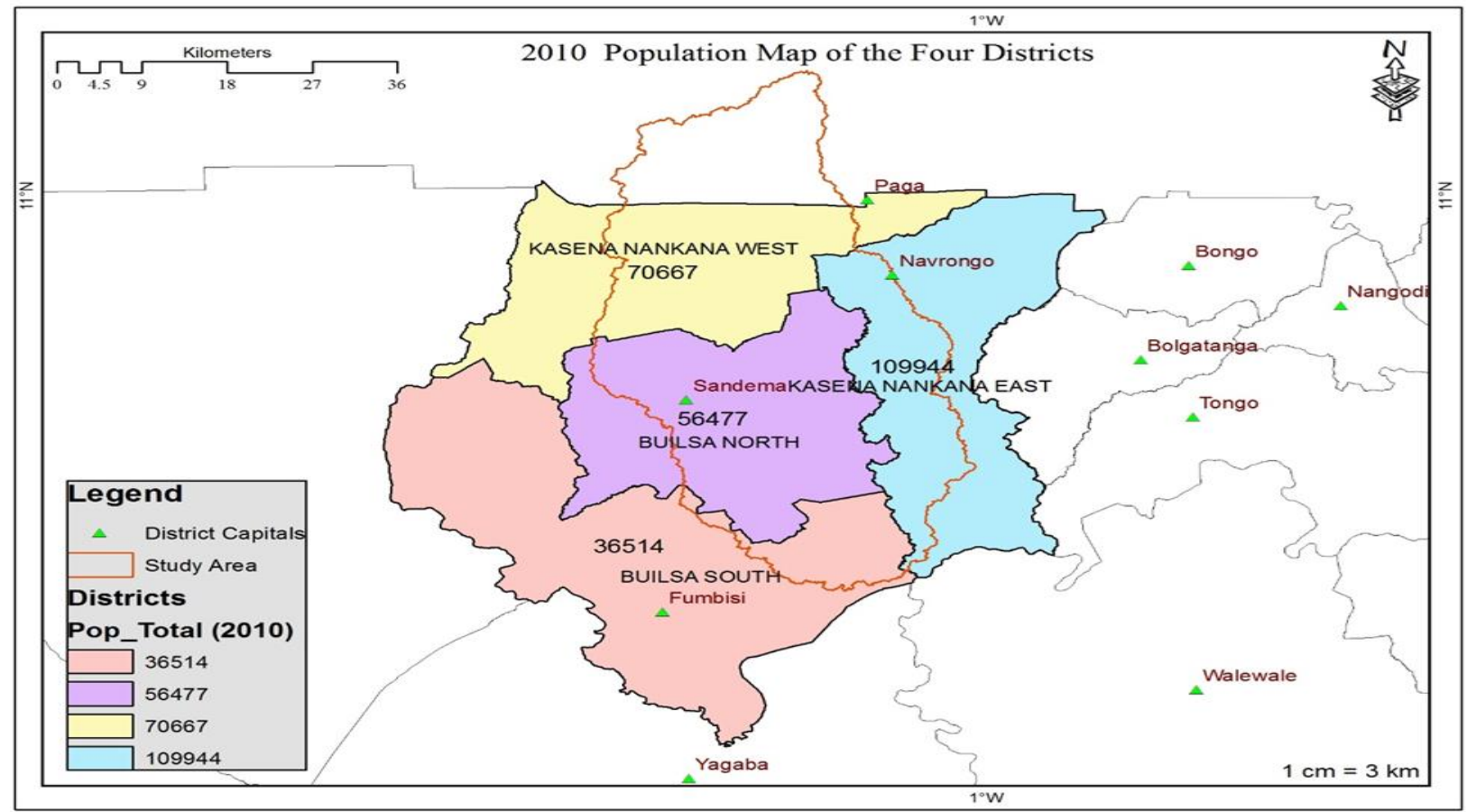

Figure 2. District level population trends within the Belepieni Catchment. (source: https://www.citypopulation.de/en/ghana/admin/09_upper_east/ with 2.2\% Annual Population Change)

\section{Rainfall and temperature distribution in the catchment}

Like most communities in Northern Ghana, the Belepieni catchment area is rural, poor and generally dependent on the ecosystem, with agriculture mainly rain fed and on subsistence basis (GSS, 2013; Boafo et al., 2014). Rainfall is uni-modal, lasting four months (July-October), with average annual rainfall ranging between 800 to $1000 \mathrm{~mm}$ (Figure 3). The average annual temperature for the catchment ranges between 28 to $29{ }^{\circ} \mathrm{C}$ (Figure 4) with the maximum temperature of Navrongo a municipality located in the catchment (See Figure 4 for location) projected to go beyond $43{ }^{\circ} \mathrm{C}$ by 2080 (Klutse et al., 2020). The climatic conditions of the Belepieni catchment can therefore be described as very harsh as compared to other areas in the country with grave implications on agriculture in the area which is generally rain fed.

ECRTD-UK https://www.eajournals.org/ ULR:https://doi.org/10.37745/bjes.2013 


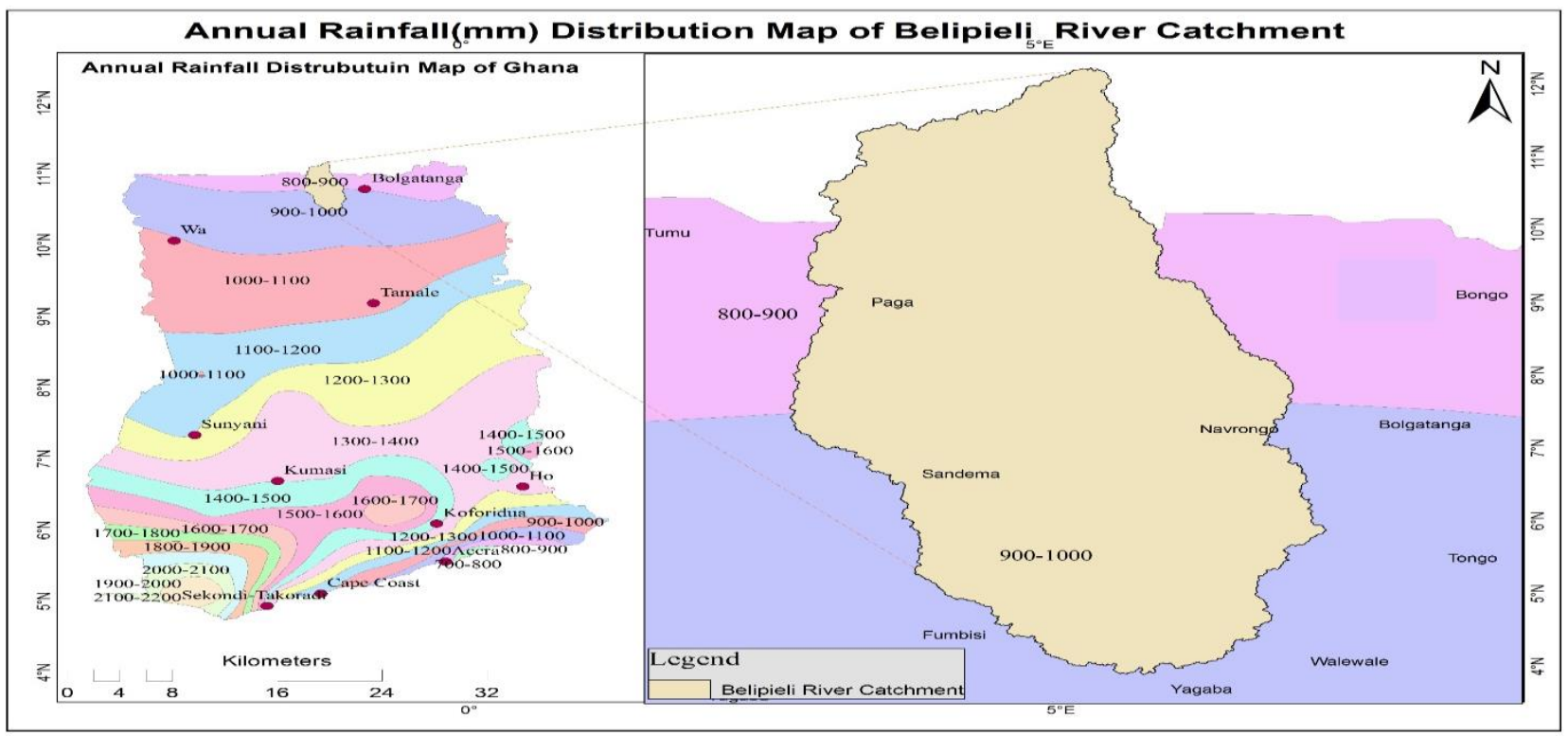

Figure 3. Average annual rainfall Distribution Map of Ghana depicting that of Belepieni Catchment

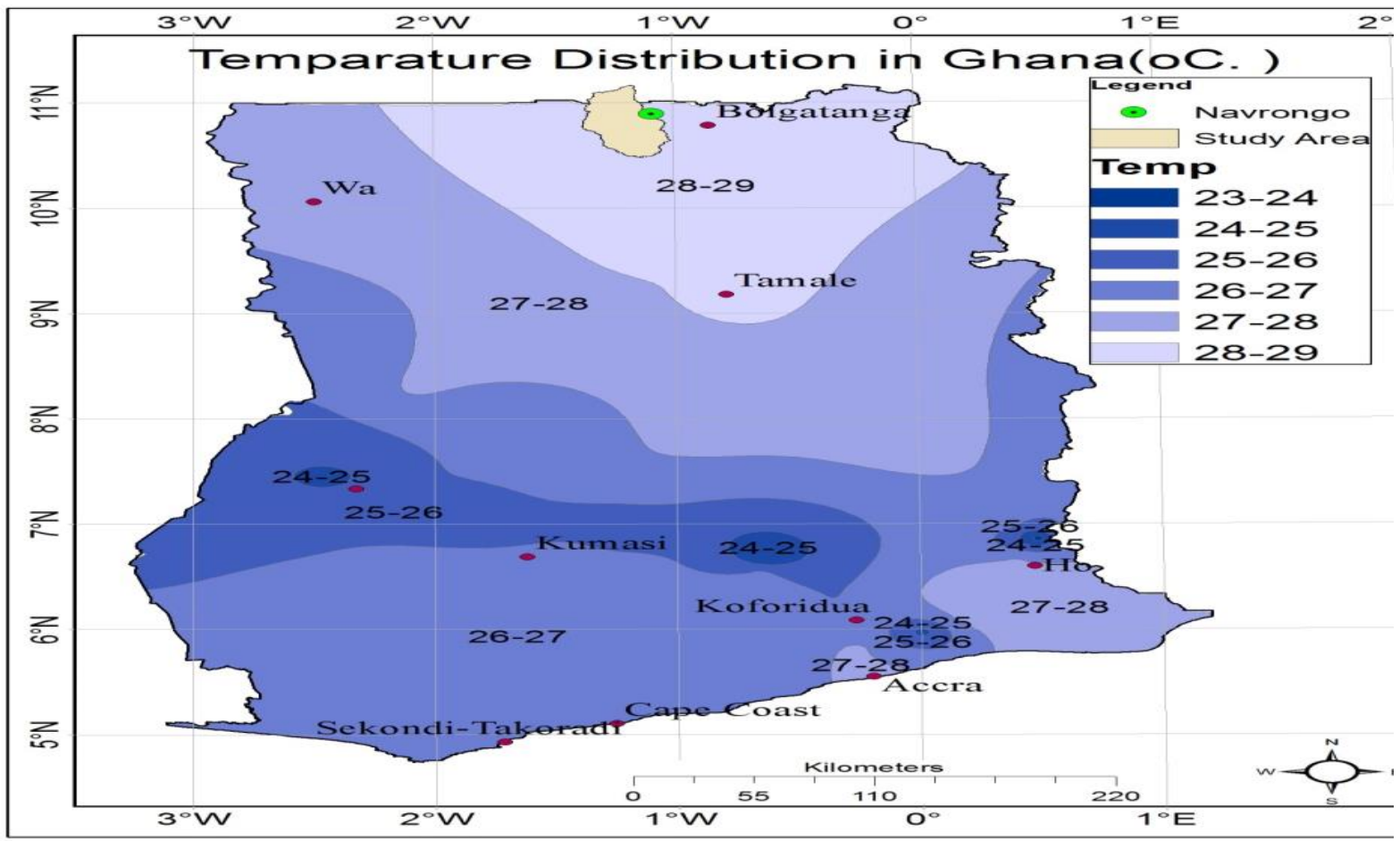

Figure 4. A map of Ghana showing average annual temperature distribution across the country and that of thestudyarea (Belepieni Catchment)

ECRTD-UK https://www.eajournals.org/ ULR:https://doi.org/10.37745/bjes.2013 


\section{Species occurrence in the catchment}

The Belipiele catchment lies in the Guinea Savannah ecological zone of Northern Ghana (Antwi et al., 2014), and has one of the biological hotspots with species occurrence of between 120 and 265 located within the catchment (Figure 5).

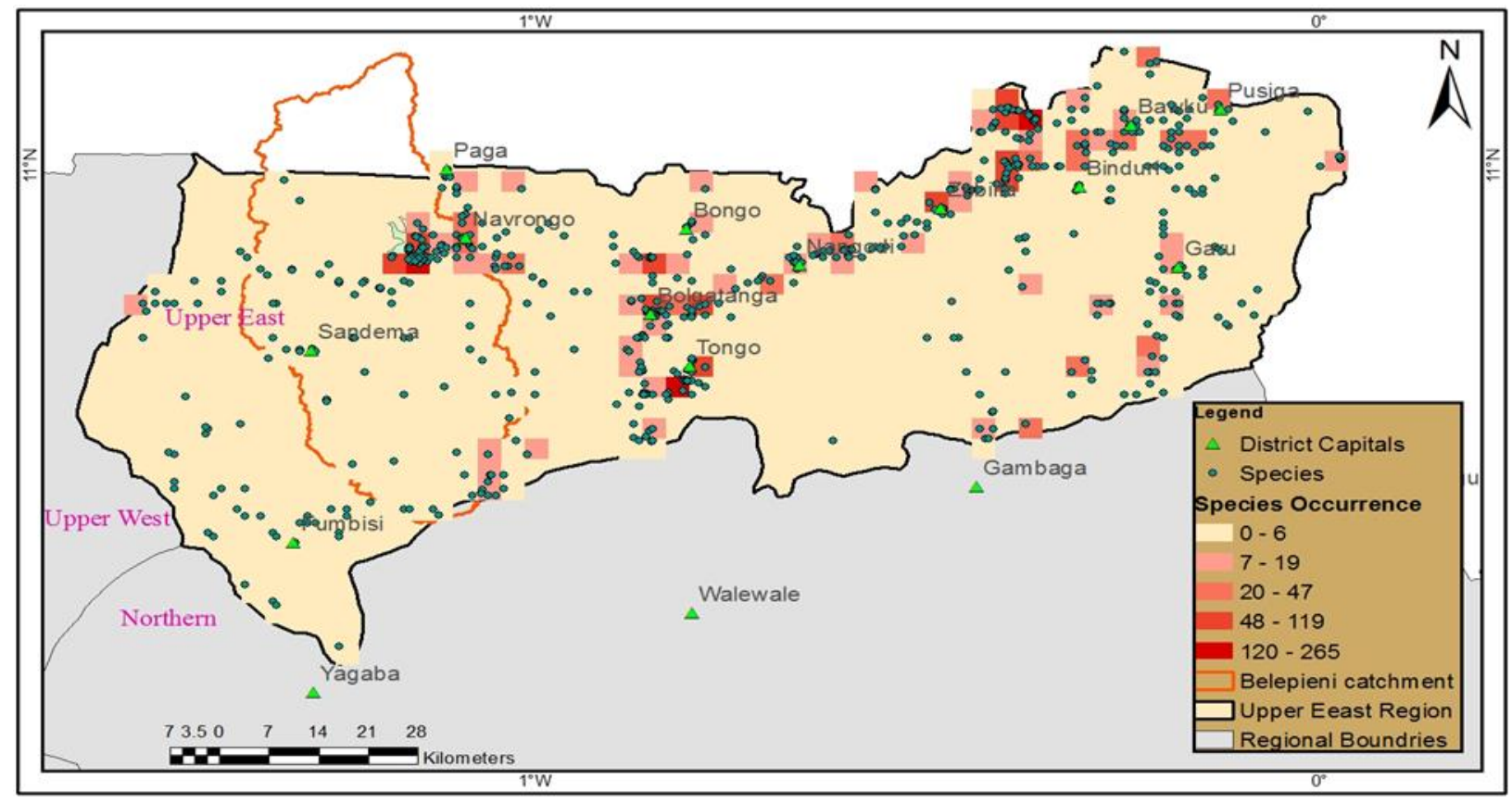

Figure 5. A map of Upper East Region showing coordinated Species occurrence depicting that of the Belipieli Catchment (Data source: Global Biodiversity Information Facility (GBIF) (https://doi.org/10.15468/dl.pqmmcp)

\section{DISCUSSION}

\section{Recent Trends and Drivers}

Over the years, the catchment has witnessed an increase in farming activities, with clearing of more lands, including marginal lands for the cultivation of vegetables such as tomato, okra, garden eggs and pepper especially in the dry season. This is driven largely by population growth and the lack of alternative livelihoods leading to an over dependence on agriculture and the yield of the natural ecosystem of the catchment for most of the basic needs of the communities. This has resulted in extensive use of agrochemicals as a means of improving soil fertility and pests control for improved yields so as to meet the food demand. This dry season farming has brought improvement to the livelihoods of the people within the catchment as it supplements for poor yields during the rainy season and also ensures some level of all year

ECRTD-UK https://www.eajournals.org/ ULR:https://doi.org/10.37745/bjes.2013 
round income. Various methods such as construction of short walls under bridges to retain some water, digging of shallow wells in the river and on the farms are used to obtain both surface and groundwater for the dry season farming. This has, however, led to siltation of the river which causes local flooding in the area during the rainy season, leading to destruction of farm crops and livestock. Other observed recent trends affecting biodiversity within the catchment are the clearing of vast lands for construction of fuel stations, driven by purely economic considerations with many oil market companies (OMCs) taking advantage of the Trans-Ecowas highway which links Ghana and Burkina-Faso.

\section{Opportunities}

Despite the observed trends facing the catchment, several opportunities exist that have the potential to improve upon the livelihoods of the communities within the area while at the same time enriching the biodiversity and ecosystem services provided. Firstly, there is a high labour force in the area that is willing to engage in activities that will support their livelihoods in a sustainable manner. For example, farmers in the area have formed informal groups for the purpose of communicating their concerns on practices they deem unhealthy. This is an opportunity that can be harnessed to form cooperative groups, which can then be given sensitization on environmental issues and how to engage in best farming practices. Also, extension services on how to increase productivity can be given to them once they have formed groups. Secondly, there is a large market for their produce especially tomato, green pepper, okra and garden eggs. Market women from all over the country come there to buy these produce. These farmers are hardly able to meet the demand of these people as the farms produce are completely harvested within a month. This market access by the farmers is a perfect opportunity that can also be used to improve the ecosystem while improving the livelihoods.

Most importantly, traditional knowledge on farming practices abounds in the communities. For example, the farmers gather the straw from their rice fields during the farming season and use it as mulching material for the vegetables in the dry season so as to reduce the evaporation rate. In addition, the farmers plant their crops in between the beds during the dry season. This way, moisture is retained for a long time as these are depressions. Also, dung is placed on the farms to attract dung beetles that are known to play an important role in soil humidity. This existing traditional knowledge can be harnessed and improved upon for a more effective soil management and ecosystem improvement.

\section{Management approach}

The management approach proposed to reverse the declining biodiversity of this catchment and also improve upon the livelihoods of the communities is based on the Community Resilience Framework (Ghana Model) developed under the Climate and Ecosystem Change Adaptation and Resilience Africa project (CECAR, 2016). The framework assesses resilience on three fronts: socio-economic, engineering and ecological (UNU-IAS, 2016). This model is suitable for application in this catchment because of the similar environmental and climatic conditions to those of the Northern region. In addition, the social background and farming practices of these communities are very similar. Socio-economic strategies such as diversification of income sources of the farmers to other areas such as bee keeping, planting of fast growing

ECRTD-UK https://www.eajournals.org/

ULR:https://doi.org/10.37745/bjes.2013 
fruit trees like mango, cashew and pawpaw should be implemented. Farmers can also include livestock and poultry such as goats, sheep, chickens and guinea fowls as an alternative source of livelihood. Farmers could also be taught simple methods that can be used to preserve their produce, such as drying them in the sun, and also how the dried produce should subsequently be stored, for example the type of material and room conditions in which to store. For the farmers to benefit from their toil, storage facilities should be provided for them since most of their produce get rotten on the farms thereby negating their efforts towards improving their livelihoods. This situation is compounded because there is no guaranteed price for the produce, with market forces alone dictating the price. Middlemen and market women have taken this opportunity to exploit these farmers who have no option but to sell their proceeds at giveaway prices or risk them getting rotten. By this, they can also have a bargain as to how much to sell their produce. Farmers should also be encouraged to effectively blend their traditional knowledge on improving soil fertility (e.g. using dung to attract dung beetles which then help to loosen the soil) with that of the modern techniques. Also, environmental policies should be made and implemented to regulate developmental activities in the area, especially the siting of gas filling stations.

In terms of improving the ecological resilience, soil moisture sensors should be provided to farmers to determine when to water and the quantity of water needed by the plants. This will eliminate over application of already scarce water. Importantly, the farmers should be educated on water harvesting techniques so that they can retain some of the run-off water during the rainy season for subsequent use in the dry season. Techniques on how to construct simple but efficient water reservoirs will be very useful in protecting the groundwater resource of the catchment.

Educating farmers on different farming methods such as mixed cropping, mixed farming, planting of leguminous plants will equally be useful in improving the soil fertility. Where livestock and poultry are included on the farm, their droppings can also be a good source of manure. Also farmers should be provided information on when, how and what to plant. This is very necessary considering the variability in the rainfall pattern. If possible, farmers should be assisted with improved seed varieties that are resistant to drought and which are high yielding with shorter yielding time. Extension officers should also train these farmers on appropriate use of agrochemicals; timing, quantity, type of agrochemicals so that indiscriminate usage and overuse are avoided. Also, environmental awareness creation to let the communities see the link between farming on the river banks and flooding, and tree cover and precipitation will help them change some of their inappropriate farming practices.

Training on modern methods of cultivation such as bed making, sowing, irrigation techniques, water transporting equipment, and time of watering will reduce water wastage and hence protect the groundwater resource. These measures can help increase the productivity, thereby reducing the pressure to clear more land for farming purposes. Finally, with a good land tenure system, farmers can also engage in agroforestry, particularly teak (Tectona grandis) which can be sold as timber.

ECRTD-UK https://www.eajournals.org/

ULR:https://doi.org/10.37745/bjes.2013 


\section{Constraints and trade-offs to implementation of the approach.}

Application of this approach is likely to come with some constraints. First is the land tenure system which allows the landowner to take back his land whenever he wants. This does not allow the farmers to make any long term sustainable investments on the land. For instance, some farmers could choose to plant fruit trees that they can depend on as alternative source of livelihood. However, considering that these trees may take a minimum of five years to fruit, the farmer may not still have the land by that time to enjoy this benefit. A change in this system to provide farmers a guaranteed period of land use will greatly help improve the biodiversity of the catchment. In the long term, the landowner still stands to benefit as the fertility of the soil would have been improved and also the economic trees would have been left for his benefit. Another constraint will be the fact that the initial conservation efforts will impose some financial burden on the part of the farmers. For instance, it may involve changing of watering equipment, purchase of sensors and improved seeds, and reduction in farmlands. However, the trade-off in this is the long term benefits in terms of saving time on watering, use of less water, and increase in productivity. These gains are likely to offset the initial cost involved. Also, farmers will have to form cooperatives in order to benefit from inputs and subsidies. Associated with these groupings are rules and regulations which might not seem favorable to some members at the beginning. For instance, issues of meetings, payment of dues, restrictions on which variety to plant may not be acceptable by all. But again, the benefits in terms of extension services, access to subsidies and loans, training, storage, pricing and marketing will far outweigh these initial inconveniences.

\section{Implications of the study to the community}

The following are the implications to the community living within the catchment:

a) The high labour force in the area could be harnessed for the formation of cooperative groups to access credit facilities for irrigation farming during the dry season which will facilitate ecosystem restoration leading to biodiversity conservation.

b) The availability of the large market within the catchment could be used to improve the livelihood of the inhabitants and the ecosystem thus preventing the over dependence on the forest resources for their survival thus preventing deforestation and destruction of the ecosystem

c) The farmers enhanced knowledge in traditional farming could help in effective soil and ecosystem management which may improve biodiversity conservation.

\section{CONCLUSION}

Unsustainable farming practices in the Belepieni catchment driven mainly by population growth have had a great negative impact on the ecosystem of the area over the years. In particular, land clearing, over abstraction of water, continuous cropping, and inappropriate use of agrochemicals have resulted in reduction of the soil fertility and also affected the water resources in the area. In order to reduce these

ECRTD-UK https://www.eajournals.org/ ULR:https://doi.org/10.37745/bjes.2013 
stresses and improve upon the ecosystem services of the area, the community-based resilience assessment in Northern Ghana, called the "Ghana model" initiated by CECAR Africa is suggested as an appropriate management approach. Despite some possible constraints to the implementation of the model, it is expected that the long term benefits to farmers and the ecosystem in general will far outweigh the cost and therefore make a compelling case for its implementation if the declining biodiversity of the catchment is to see any improvement.

It is recommended that a) the Community Resilience Management approach proposed should be implemented by the community to aid in the reversal of the declining biodiversity in the catchment $b$ ) storage facilities for agricultural produce should be established by the community to reduce postharvest losses which will improve livelihood and c) environmental policies should be made by the community to regulate developmental activities within the catchment for instance the siting of fuel stations to protect the ecosystem thereby ensuring biodiversity conservation.

\section{References}

Adekola, O, Mitchell, G \& Grainger, A. (2015). Inequality and ecosystem services: the value and social distribution of Niger Delta wetland services', Ecosystem Services, Vol 12, 42-54.

Ampadu, B., Sackey, I., and Cudjoe, E. (2019). Rainfall distribution in the Upper East Region of Ghana,1976 - 2016. Ghana Journal of Science, Technology and Development, 6(2), 4559.https://doi.org/10.47881/ 168.967x

Antwi, E.K., Boakye-Danquah, J., Asabere, S.B., et al. (2014). Land use and landscape structural changes in the ecoregions of Ghana. Journal of disaster research. 9 (4) 452-467.

Bennett EM, Peterson GD, Gordon LJ: Understanding relationships among multiple ecosystem services. Ecol Lett 2009, 12:1394-1404.

Blumetti AM, DiManna P, Ferreli L, Florenza D, Vittorl E: Reduction of environmental risk from capable faults: the case of the Eastern Etna region (eastern Sicily, Italy). Quaternary Int 2007, 173:45-56.

Boafo, Y.A., Saito O. and Takeuchi K. (2014). Provisioning ecosystem services in rural savanna landscapes of Northern Ghana. Assessment of supply, utilization and drivers of change. Journal of disaster research. 9 (4): 501-515

Boadi, S. A. and Owusu, K (2017): Impact of climate change and variability on hydropower in Ghana, African Geographical Review, pp 1- 15, DOI:10.1080/19376812.2017.1284598

Bommarco R, Kleijn D, Potts SG: Ecological intensification: harnessing ecosystem services for food security. Trends Ecol Evol 2013, 28:230-238.

Canadell, J. G., Le Quéré, C., Raupach, M. R., Marland, G., Bopp, L., Ciais, P\& Friedlingstein, P. (2009). Trends in the sources and sinks of carbon dioxide. Nature Geoscience, 2(12) : 831-836.

CECAR Africa report (2016). Enhancing resilience to climate and ecosystem changes in semi-arid Africa: An integrated approach.

Chapin FS, Chapin MC, Matson PA, Vitousek P: Principles of Terrestrial Ecosystem Ecology. Springer; 2011.

FAO (2018). Sustainable Agriculture for Biodiversity, 19577 EN/ 105/ 2018

ECRTD-UK https://www.eajournals.org/

ULR:https://doi.org/10.37745/bjes.2013 
British Journal of Environmental Sciences

Vol.10, No.2, pp. 1-12, 2022

ISSN 2054-6351 (print),

ISSN 2054-636X (online)

GSS (Ghana Statistical Service), 2007 Pattern and trends of poverty in Ghana (1991-2006). GSS, Accra, Ghana.

Ghana statistical Service, P. and H. C. (2014).

https://www.citypopulation.de/en/ghana/admin/09_upper_east/ with 2.2\% Annual Population Change

https://www.citypopulation.de/en/ghana/admin/09_upper_east/)

Intergovernmental Panel on Climate Change, IPCC, (TAR) (2001) Third Assessment Report (TAR) of the Intergovernmental Panel on Climate Change. Parts 1, 2 and 3, Synthesis Report and Policy

Makers Summaries. Cambridge University Press, Cambridge, UK.

Intergovernmental Panel on Climate Change, IPCC (2007): Climate Change 2007: Impacts, Adaptation and Vulnerability. Contribution of Working Group II to the Fourth

Assessment Report of the Intergovernmental Panel on Climate Change, M.L. Parry, O.F.

Canziani, J.P. Palutikof, P.J. van der Linden and C.E. Hanson, Eds., Cambridge

University Press, Cambridge, UK, 976pp.

Intergovernmental Panel on Climate Change, IPCC (2019). Summary for Policymakers. In:

Globalwarming of $1.5^{\circ} \mathrm{C}$. An IPCC Special Report on the impacts of global warming of $1.5^{\circ} \mathrm{C}$ above pre-industrial levels and related global greenhouse gas emission pathways, in the context of strengthening the global response to the threat of climate change, sustainabledevelopment, and efforts to eradicate poverty [V. Masson-Delmotte, P. Zhai H. O. Pörtner, D. Roberts, J. Skea, P. R. Shukla, A. Pirani, W. Moufouma-Okia, C. Péan, R. Pidcock, S. Connors, J. B. R. Matthews, Y. Chen, X. Zhou, M. I. Gomis, E.Lonnoy, T. Maycock, M. Tignor, T. Waterfield (eds.)]. World Meteorological Organization,Geneva, Switzerland, $32 \mathrm{pp}$.

Klutse, N. A. B., Owusu, K. and Boafo, Y. A. (2020). Projected Temperature Increase overNorthern Ghana, SN Applied Sciences, 2 (1339): 1 - 14

Lepczyk, C. A., Aronson, M. F. J., Evans, K. L., Goddard, M. A., Lerman, S. B. and J. S.

Macivor (2017). Biodiversity in the City: Fundamental Questions for Understanding the

Ecology of Urban Green Spaces for Biodiversity Conservation. BioScience 67 (9): 800 -

809 Mastrandrea, K.J. Mach, T.E. Bilir, M. Chatterjee, K.L. Ebi, Y.O. Estrada, R.C. Genova, B.

Girma, E.S. Kissel, A.N. Levy, S. MacCracken, P.R. Mastrandrea, and L.L. White (eds.)].Cambridge University Press, Cambridge, United Kingdom and New York, NY, USA,pp. 1199-1265.

Millennium Ecosystem Assessment (2005). Ecosystems and Human Well-being: Synthesis.IslandPress, Washington, DC. World Resources Institute

Niang, I., O.C. Ruppel, M.A. Abdrabo, A. Essel, C. Lennard, J. Padgham, and P. Urquhart, (2014): Africa. In: Climate Change 2014: Impacts, Adaptation, and Vulnerability. Part B: Regional Aspects. Contribution of Working Group II to the Fifth Assessment Report of the Intergovernmental Panel on Climate Change [Barros, V.R., C.B. Field, D.J. Dokken, M.D.

Power AG: Ecosystem services and agriculture: tradeoffs and synergies. Philos Trans Roy Soc B-Biol Sci 2010, 365:2959-2971

Robertson GP, Swinton SM: Reconciling agricultural productivity and environmental integrity: a grand challenge for agriculture. Front Ecol Environ 2005, 3:38-46.

The IPBES Conceptual Framework - connecting nature and people Current Opinion in Environmental Sustainability 2015, 14:1-16

UNEP 2008. Biodiversity, on the Move to 2010, viewed on 24

UNU-IAS \& IR3S/UTIAS (2016). Socio-ecological production landscapes and Seascapes in

ECRTD-UK https://www.eajournals.org/

ULR:https://doi.org/10.37745/bjes.2013 
British Journal of Environmental Sciences

Vol.10, No.2, pp. 1-12, 2022

ISSN 2054-6351 (print),

ISSN 2054-636X (online)

Africa. United Nations University for the Advancement of Sustainability, Tokyo.

Vellekoop J, Sluijs A, Smit J, Schouten S, Weijers JWH, Damste JSS, Brinkhuis H: Rapid shortterm cooling following the Chicxulub impact at the Cretaceous-Paleogene boundary. ProcNatl Acad Sci U S A 2014, 111:7537-7541.

World Bank (2015). Poverty reduction in Ghana: Progress and Challenges. The World Bank Group, Washington D. C.

Zhang W, Ricketts TH, Kremen C, Carney K, Swinton SM: Ecosystem services and dis-services to agriculture. Ecol Econ 2007, 64:253-260. 